\title{
SUSTAINABLE WAYS OF DRYING GRAINS: THREE CONCEPTS
}

\section{JOHANNES. P. ANGULA \& FREDDIE INAMBAO*}

Department of Mechanical Engineering, University of KwaZulu-Natal, Durban, South Africa

\begin{abstract}
The use of renewable energy has rapidly gained acceptance in many industries worldwide, not only for electricity generation but for thermal applications as well. In the food industry and many other agricultural applications, renewable energy is utilized in aiding the drying processes of food products such as grains. This paper focuses on sustainable ways of drying grains using biomass energy and solar energy technologies. The aim of the research study was to investigate drying methods that rely on green energy solutions in order to optimize the drying of grain. The research conducted identified three conceptual designs that were found to be economically viable for the design and construction of sustainable grain dryer systems using biomass energy and solar energy for heat generation. As discussed in this paper, concept 1 uses an air-to-air heat exchanger to transfer the heat generated by the biomass burner in order to initiate the drying process. Concept 2 uses the same principles as those of concept 1 but the heat from the biomass burner is transferred through a combination of an air-to-water heat exchanger and a radiator. Due to the abundant production of corn and sugar cane in South Africa, corn stovers and sugar cane waste are seen as potential sources of biomass energy for these concept designs. Concept 3 relies on the use of solar energy. In this concept, a forced convection multilayer solar dryer system is assisted by an electric heater which is powered through a solar panel system. This allows an electric heater to be used during off-peak sunshine hours such as when it is cloudy or at nighttime.
\end{abstract}

KEYWORDS: Biomass Energy; Solar Energy; Design; Performance \& Grains

Received: Jun 04, 2021; Accepted: Jun 24, 2021; Published: Aug 03, 2021; Paper Id.: IJMPERDOCT20211

\section{INTRODUCTION}

Drying agricultural food products is one of the oldest and most efficient methods of preserving food for a long period. Some of the drying methods that are widely used are traditional open-sun drying and oven drying. Although such drying methods are popular, the food products are exposed to high temperatures for longer periods and dried in an unhygienic manner which has adverse effects on the physicochemical and nutritional properties of the products $[5,6]$. Some of the agricultural food products that are widely farmed and consumed are grains such as corn, wheat, sorghum, and rice. These types of grains form part of the staple diet for the majority of people across the globe and their consumption increases day by day. They serve as an important source of carbohydrates and provide dietary fiber which helps in the reduction of bad cholesterol in the body [1,2]. The process of production of quality grains does not only include controlled farming methods but also post-harvesting methods such as efficient drying methods. As technology evolves, various sustainable ways of drying grains have been developed. Sustainable ways of grain drying refer to efficient drying processes that are cost effective and have minimum impact on the environment [3]. In most grain farming industries, it is a necessity that the grains meet some specific requirements after drying such as their size, moisture content, etc. The selection of a suitable drying process and the right grain dryer has a big influence on the quality, size and final moisture content of grains $[3,4]$.

Whether energy storage can be justified depends critically on the nature of the demand and supply, and the 
conditions of operation since some energy storage systems can be charged and discharged several times a day, while others are interseasonal [7]. In many industrial drying processes, controlled drying using fossil fuel is most commonly practised. However, the use of fossil fuel for energy generation has many negative impacts such as high running costs, environmental effects, and gradual depletion of its reserves [8,9]. This necessitates the need for further research on harnessing solar energy or the use of other alternative sources of energy to improve drying processes and lead to a reduction in the use of fossil fuels.

Ongoing research on grain drying and preservation aims to improve the quality and capacity of grains in order to develop sustainable ways of drying grains without compromising on quality. Some of the proposed sustainable ways of drying grains involve the use of energy efficient methods such as biomass dryers and solar dryers. Solar energy is abundant and inexhaustible and has been used for ages to dry food products. However, with improved solar dryer efficiency and production capacity, this process can be enhanced. The use of biomass energy to dry food products such as grains is also regarded as one of the most efficient and clean energy methods and is cost effective. In biomass energy generation, the energy is produced by plant or animal materials such as wood, energy crops, forest waste and other types of organic matter. The use of a biomass grain dryer can be very useful and cost effective in countries with abundant sources of biomass such as South Africa. In South Africa, organic matter that can be used as sources of biomass includes residues of sugar cane, corn waste, and other types of organic matter that are produced in large quantity in the country. South Africa also has good sunshine hours throughout the year. Most areas of the country have annual average of at least 2500 hours of sunshine while the daily solar irradiance ranges from a minimum of $4.5 \mathrm{kWh} / \mathrm{m}^{2}$ to a maximum of $6.5 \mathrm{kWh} / \mathrm{m}^{2}[9,10]$. This paper presents the discussion of two design concepts that are proposed as sustainable ways of drying grains. The three concepts presented in this paper involves the use of biomass energy to dry grains and the use of an improved solar grain dryer that enhances thermal efficiency. A brief overview of typical grains that are popular and widely consumed is also presented.

\section{LITERATURE REVIEW}

The concept of developing sustainable ways of drying grains through renewable energy strategies is a crucial aspect of food sustainability and energy saving. It allows food drying processes to be optimized and reduces operational costs without compromising safety. Since the $19^{\text {th }}$ and $20^{\text {th }}$ centuries, the consumption of dried products such as grains has increased because of associated benefits such as the ability to be preserved for longer periods and the occupation of less storage area in comparison to fresh products [11]. Research has also shown that various grains have different levels of moisture content for safe storage. Depending on the application, the threshold limit for most grains is below $15 \%$ moisture content. The threshold limit sets a boundary for the grains to prevent them from undergoing any chemical or physical changes while being stored. Grains, like many other food types, havea tendency to retain water in their structure depending on the storage conditions, hence the necessity for developing sustainable drying methods to improve grain drying processes. In this paper, the literature review focuses on the drying of some of the popular and crucial types of grains that are consumed worldwide. The grains of interest in this paper are (i) corn, (ii) wheat, (iii) sorghum, and (iv) rice.

\subsection{Grains Drying}

Grains such as maize/corn and rice are amongthe most important cereal crops which are popular and widely consumed as part of the staple diet in many countries in the world particularly in most African countries [12]. Maize was initially grown at a subsistence farming scale however due to its popularity, demand, and nutritional benefits, its production has grown to commercial farming scale. In many subsistence farming practices maize/corn is still dried using the traditional open-sun 
drying method - a method which is regarded as unhygienic and degrades the quality and nutritional value of grains [13]. According to many studies (as reviewed by Kenneth et al. [14]) the maximum moisture content for storage of maize for a period of more than 6 months is recommended to be $13 \% \mathrm{wb}$.

Modern ways of drying have been researched and developed to combat the effects that arise from using traditional drying methods. One of the most efficient, environmentally friendly, and cost-effective ways of drying agricultural products such as maize is through the use of solar dryers or biomass dryers. A study by Adekanye et al. [12] was conducted on the development of a maize-on-cob dryer for small-scale farmers as shown by the schematic diagram in Figure 1.

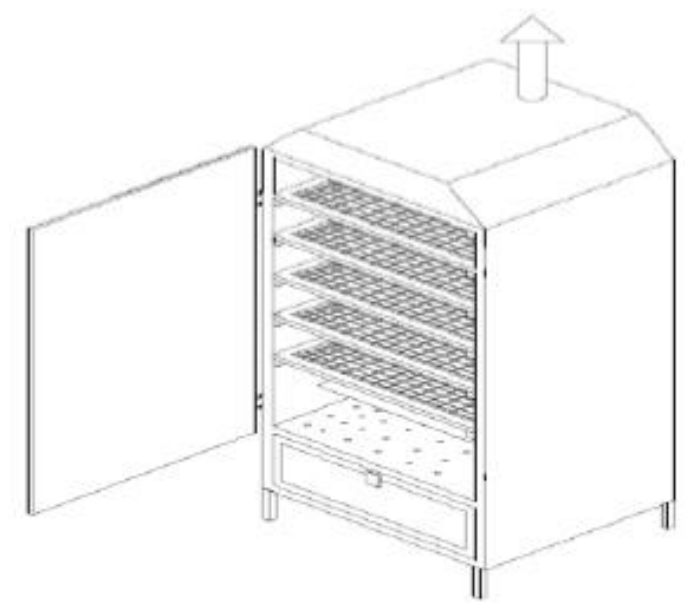

Figure 1: Schematic view of the Prototype Maize-on-Cob Dryer [12].

In their experiment, the dryer derived its drying power from maize residues that were used as a source of heat. The prototype dryer they tested consisted of a drying chamber, chimney, five trays, corn waste container, electric motor, and a fan to induce forced convection during the drying process. Based on their experiment, the dryer was able to dry two $\mathrm{kg}$ of maize-on-cobs in seven hours from an initial moisture content of $76.80 \%$ (wb) to $13.32 \%$ (wb). In another research study conducted by Kaaya and Kyamuhangire [15], a biomass-heated natural convection dryer was used to dry maize in order to improve the quality of grains during storage. Their study indicated that using a biomass dryer significantly reduced drying time and improved grain quality although the storage quality of grains depended on the storage form [15].

In most industries, maize drying is still practiced using the conventional drying method of open-sun drying, a method that sometimes leads to unfavorable grain quality. In some literature, the idea of incorporating thermal energy storage systems in the drying practices of grains such as maize has been proposed. Thermal energy storage (TES) systems are smart technology developed to enhance thermal efficiency. The TES system works on the basis of a thermal energy sensitive material (liquid, solid, or phase change material) to store solar energy captured during peak hours and released during off-peak hours and used for the drying process $[9,16]$. It is assumed that attaching this system to a solar dryer or a biomass dryer can improve the drying process significantly. Figure 2 shows a concept design of a thermal energy storage system that uses a bed of rocks to store solar thermal energy for later use. 


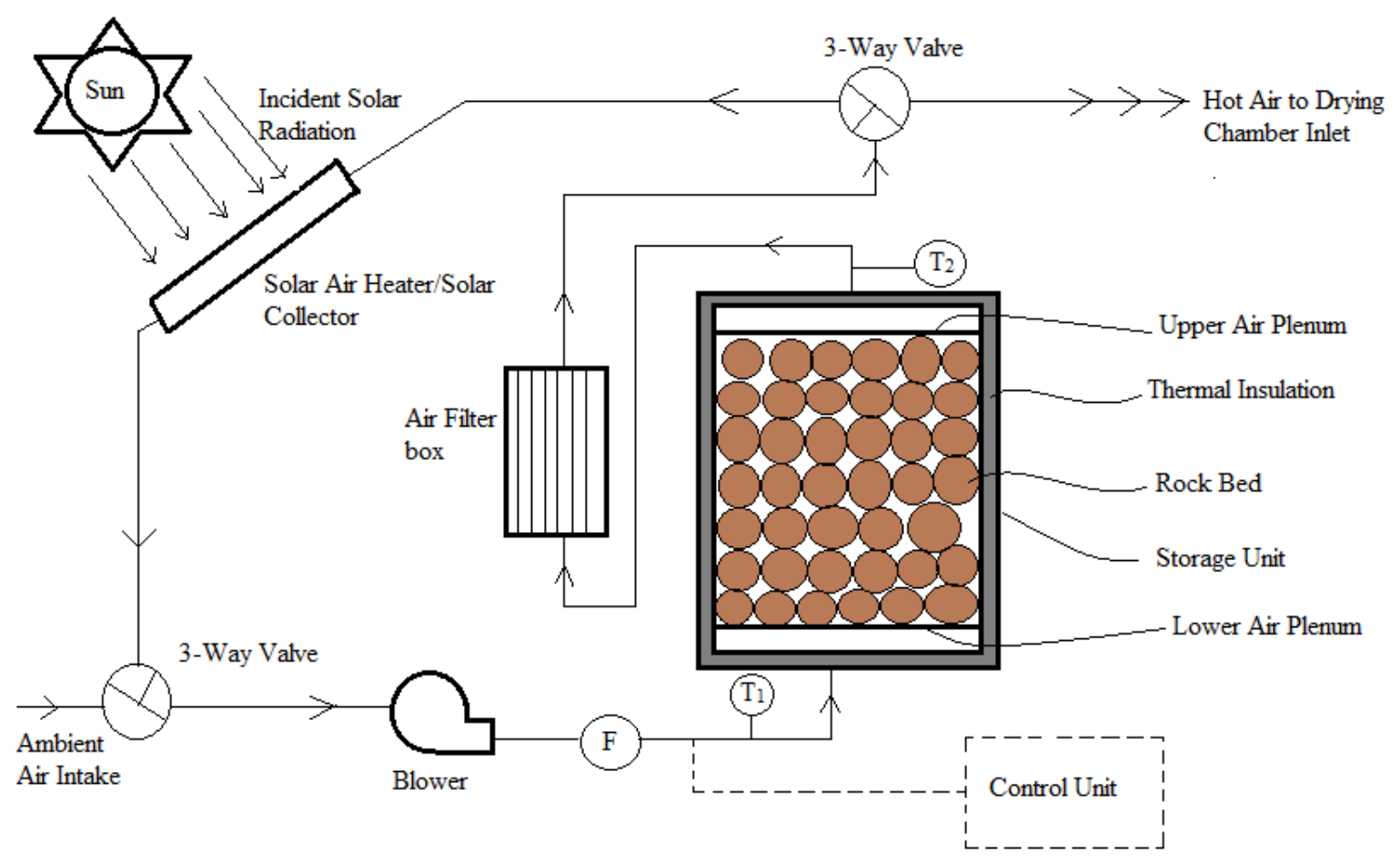

Figure 2: Conceptual Design Layout for the Rock Bed Solar Thermal Energy Storage System [9].

The system was designed as a standby unit for a solar dryer system that supplied hot air to the drying chamber for drying during off-peak periods such as during cloudy hours or nighttime. Hot air was circulated by means of a motor blower through air filters and a solar collector [9].

A review presented by Ahmad [17] on properties and bulk drying of biomass indicates that biomass has surpassed hydropower as the single largest renewable energy source. More than half of this renewable energy is generated from the forest products industry as shown in Figure 3. The increase in demand for biomass for energy is a clear indication that renewable energy is the way to go in meeting the demand for energy. Biomass as a source of energy is a partial solution to the fossil fuel crisis that is readily available through the application of existing technology and abundant supply [17]. 


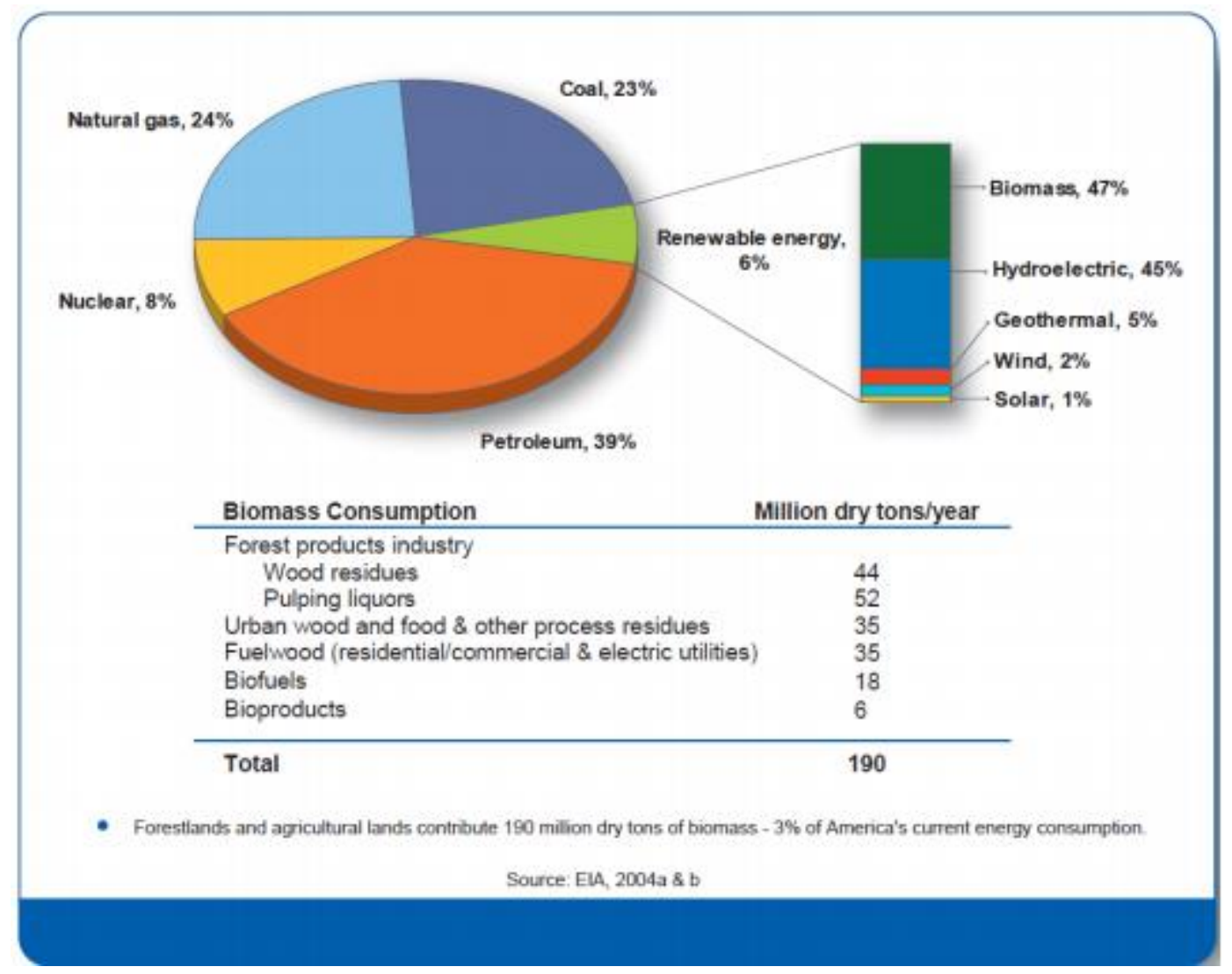

Figure 3: Biomass Resource Consumption [17].

In general, there are two main types of biomass resources: (i) agricultural resources and (ii) forest resources. The primary contributors of agriculture resources are crop residues from major crops such as corn stover, small grain straw, grains (corn and soybeans) used for ethanol, biodiesel and bioproducts, perennial grasses and perennial woody crops [17]. Primary constituents of forest resources are logging residues from conventional harvest operations and residues from forest management and land clearing operations, removal of excess biomass (fuel, treatments) from timberlands and other forestlands, and fuel wood extracted from forestlands [17,18]. With the advancement in technologies, there is great potential for obtaining vast quantities of biomass materials for bio-energy generation particularly in countries such as South Africa where agricultural resources are present in vast quantities. South Africa has a big agricultural sector particularly in the production of maize. This presents an opportunity for using corn residues such as corn stover and other residues in fulfilling the need for biomass energy generation. Despite electrical energy generation, this energy can be used in the drying processes for agricultural products.

\section{CONCEPTUAL DESIGN FOR SUSTAINABLE GRAIN DRYING}

In order to ensure agricultural crops such as grains are dried through sustainable ways, the drying methods need to be improved through research and development. Although there are many sustainable ways that grains can be dried, it is proposed that one of the cheapest yet effective ways of drying grains can be through using renewable energy systems such as solar energy and biomass energy. Two conceptual designs for using biomass as a source of energy for the grain dryer are proposed and discussed in this section, and one conceptual design for using solar energy is proposed and discussed. 


\subsection{Concept 1: Biomass Grain Dryer using an Air-to-Air Heat Exchanger}

South Africa is a country with a big agricultural sector which presents a great opportunity for using crop residues such as corn stovers and sugar cane to produce biomass energy. Corn stover is a good source of biofuel and is generally composed of cobs, leaves, soil, and stalks [19]. According to Bennett et al. [20], corn stover can profitably be used as a source of energy to dry corn grains due to its high calorific value. The energy content of corn stovers varies depending on the type of corn. However, in most cases, the calorific values of corn stovers range between $16.4 \mathrm{MJ} / \mathrm{kg}$ and 17.4 MJ/kg [21,22]. Figure 4 presents a conceptual design of a biomass grain dryer with an air-to-air heat exchanger. This system is designed on the basis of using corn stovers as a biomass product to generate the energy necessary to dry grains.

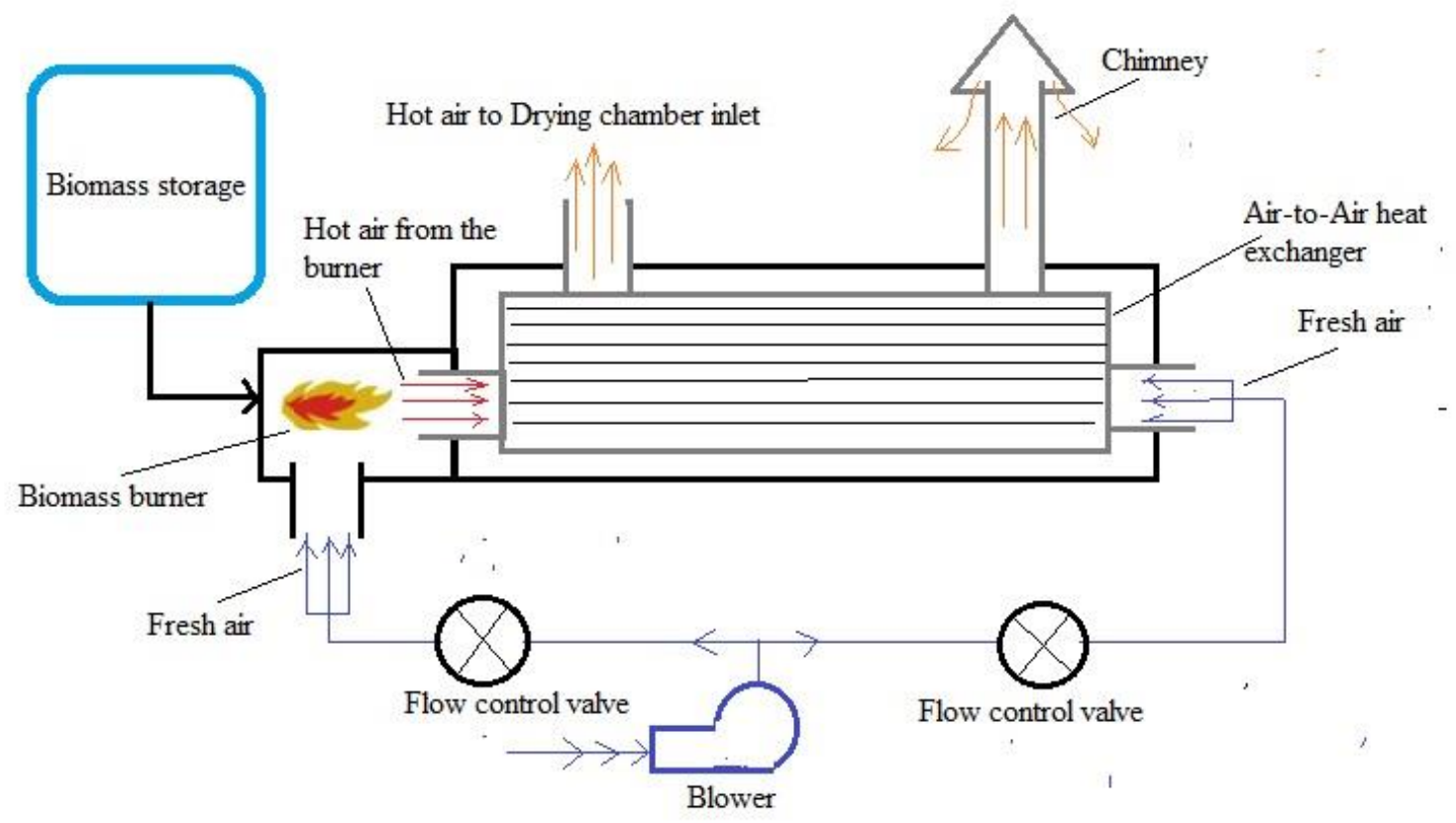

Figure 4: Conceptual Design Layout for a Biomass Grain Dryer using an Air-to-Air Heat Exchanger.

The design presented in Figure 4 is designed to supply hot air to the drying chamber. Corn stovers from the biomass storage are fed to the biomass burner. In the biomass burner, the biomass is ignited and the hot combustion gasses are blown to the heat exchanger where energy transfer takes place. Through the use of a control valve, some of the fresh air from the blower is sent to the heat exchanger where it gets heated and exits the heat exchanger as hot air which is channeled to the drying chamber inlet. It is possible to have separate blowers, but the design in Figure 4 takes advantage of incorporating one main blower to supply air to both the biomass burner and to the heat exchanger. Flue gasses from the biomass burner going through the heat exchanger escape to the surrounding environment through the chimney. With an improved design, it is also possible to incorporate a filtration system that will filter out harmful gasses before they escape to the environment.

\subsection{Concept 2: Biomass Grain Dryer using an Air-to-Water Heat Exchanger with a Radiator}

The second concept proposed for using biomass energy to dry grains is using an air-to-water heat exchange system coupled with a radiator to transfer the energy to the drying chamber. This conceptual design is presented in Figure 5 and is similar in principle to the design concept presented in Figure 4. The only major difference is that with this design an air-to-water heat exchanger and a radiator are used for the heat transfer processes rather than only an air-to-air heat exchanger. The 
design presented by the layout in Figure 5 is also developed on the basis of using agricultural residues such as corn stovers as the source of biomass energy.

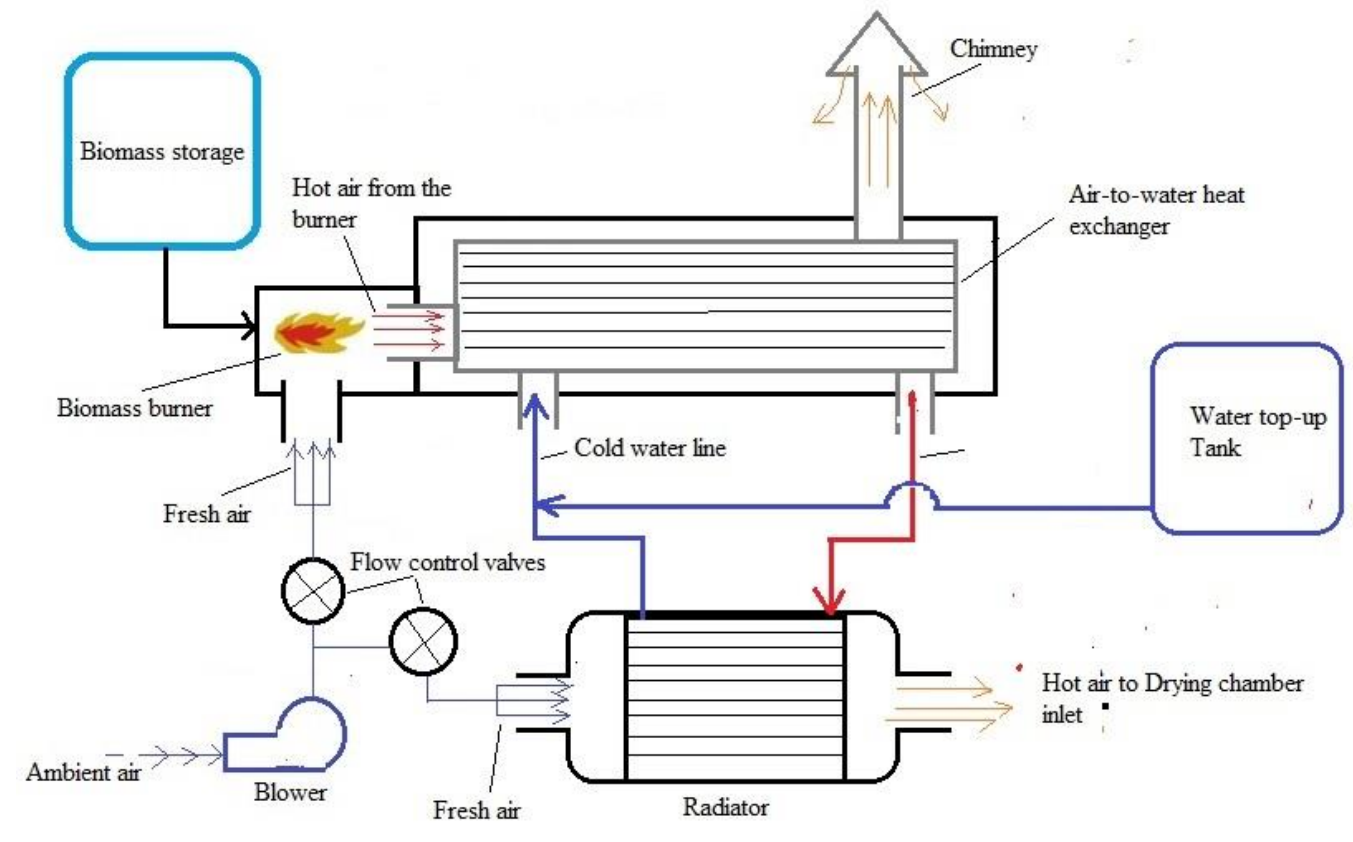

Figure 5: Conceptual Design Layout for a Biomass Grain Dryer using an Air-to-Water Heat Exchanger and a Radiator.

Similar to the previous design, biomass is fed into the combustion chamber where the biomass burner ignites the biomass. The hot gasses from the burner are sent to the heat exchanger where heat transfer between the hot gasses and cooled water takes place. Basically, water is recirculated between the radiator and the heat exchanger. Heat transferred from the heat exchanger side by the water is then transferred to the air at the radiator side. Some of the fresh air from the blower entering through the control valves is pushed through the radiator fins in order to extract as much heat from the hot water that is running through the radiator. The heated air from the radiator is then channeled to the inlet of the drying chamber for drying purposes. Although this design layout is more complex than the previous design, the thermal efficiency of this design is anticipated to be better than the design with an air-to-air heat exchanger only. This is because water has a much higher thermal conductivity than air. Inside the heat exchanger, heat from the hot gasses of the biomass burner will be transferred much more quickly when using water rather than air. Despite this, the design with an air-to-air heat exchanger is simple and cost effective to run compared to the design with an air-to-water heat exchanger.

\subsection{Concept 3: Forced-Convection Solar-Assisted Multilayer Grain Dryer}

The third design concept proposed employs the use of solar energy integrated with photovoltaic (PV) solar panels. In this design, the drying system is a forced-convection mixed-mode solar dryer coupled with an electric heater powered by the solar panel system. Figure 6 depicts the schematic of the concept design for the forced-convection solar-assisted multilayer grain dryer. 


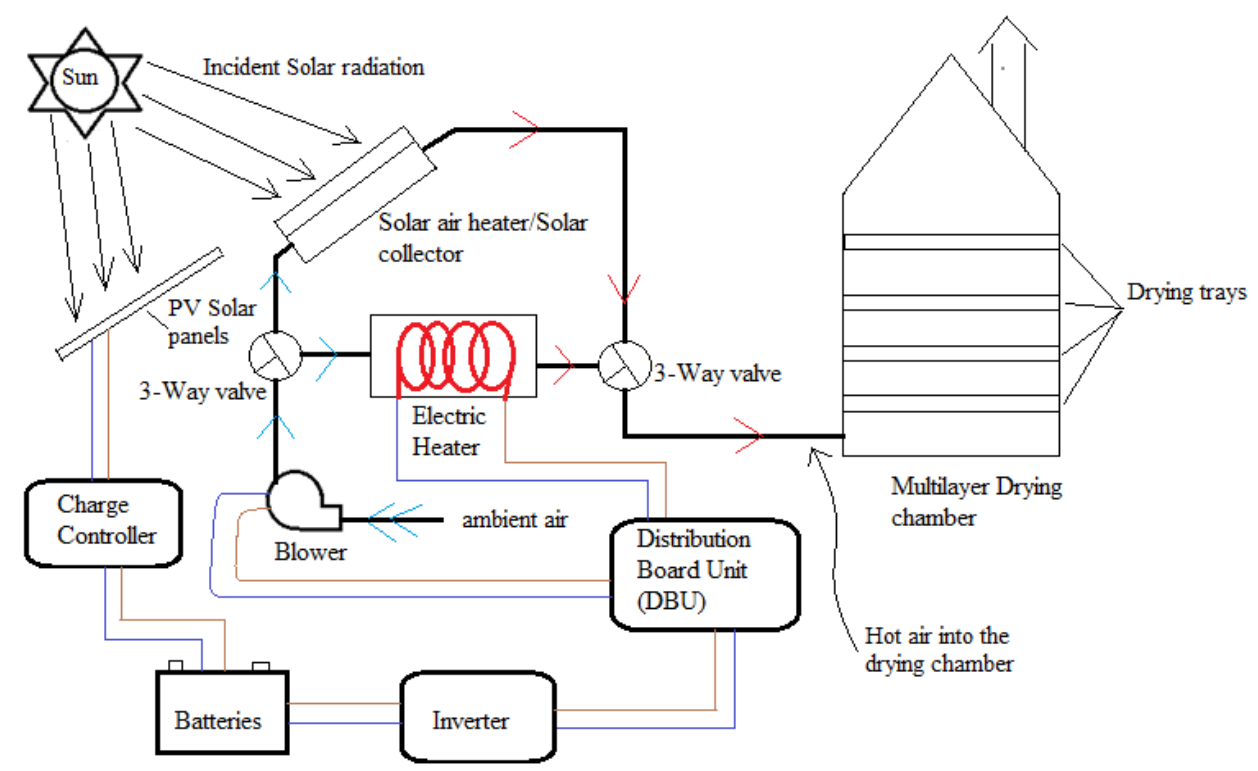

Figure 6: Conceptual Design Layout of the Forced-Convection Solar-Assisted Multilayer Grain Dryer.

The idea presented in Figure 6 emphasizes the use of solar energy to dry grains during peak and off-peak sunshine hours in order to maximize the drying process. During peak sunshine hours the drying process is achieved through the solar air heater/solar collector channel. During this period, incident sun rays will heat the absorber in the solar collector which will, in turn, heat the ambient air that is pushed through it from the blower. Through an induced forced convection process, hot air exiting the solar collector will enter the multilayer drying chamber to allow moisture evaporation to take place. At the same time during peak sunshine hours, the PV solar panels are used to charge the batteries. During off-peak sunshine hours, the inverter and DBU electrical energy stored in the batteries is used to power the electrical heater which will generate the heat necessary to cause moisture evaporation in the drying chamber. The 3-way control valves ensure that the flow of air is channeled to the right flow path. The blower which pushes air to the drying chamber is also powered by the solar panel system; in this way, solar energy is optimized.

\section{CONCLUSIONS}

A literature review on sustainable ways of drying grains was conducted. Three conceptual designs suitable for drying grains were identified as viable options. The three concepts rely on biomass energy and solar energy principles. The first concept design uses an air-to-air heat exchanger to transfer heat derived from the biomass burner in order to dry grains. The second concept design is similar in principle to the first concept except that in this design a combination of an air-towater heat exchanger and a radiator is used. In this concept, heat is still derived from the biomass burner. Due to the high production of maize and sugar cane in South Africa, both concept 1 and concept 2 are assumed to use corn stovers or sugar cane waste as the source of biomass energy. The third concept uses a forced convection multilayer solar dryer that is assisted by an electric heater powered by solar panels. In thisconcept, an electric heater powered through a solar panel system can be used during off-peak hours to provide the heat necessary for the drying process. This study has concluded that these concept designs can be implemented to improve grain drying processes and increase production.

\section{RECOMMENDATIONS}

This paper has presented concepts that are seen as having the potential to aid in drying grains in a sustainable manner. Due 
to the limited scope of works cited, it is recommended that further research be conducted by means of experimental studies for the three conceptual designs discussed in this paper.

\section{REFERENCES}

1. Salunkhe, D. K. and Kadam, S. S. Handbook of Fruit Science and Technology: Production, Composition, Storage, and Processing. NewYork: Marcel-Dekker, 1995.

2. Angula, J.P. and Inambao, F. L. Review of Solar Grain Drying. International Journal of Mechanical Engineering and Technology, 10(11),2019, pp. 275-296.

3. Real-Olver, J.D. Introductory Chapter: Principles of Sustainable Drying. In Real-Olver, J. D. (ed.). Sustainable Drying Technologies. 2016, pp. 1-5. http://dx.doi.org/10.5772/64614

4. Kudra, T. and Mujumdar, A.S. Advanced Drying Technologies. New York: Marcel Dekker. 2004.

5. Kwok, B.H.L., Hu, C., Durance, T., and Kitts, D.D. Dehydration Techniques Affect PhytochemicalContents and Free Radical Scavenging Activities of Saskatoon Berries (Amelanchieralnifolia Nutt.). Journal of Food Science,69(3), 2004, SNQ122SNQ126.https://doi.org/10.1111/j.1365-2621.2004.tb13381.x

6. Singh, A P., Mandal, R., Shojaei, M. Singh, A., Łukasz, P. K., Ligaj, M., Pawlicz, J. andJarzębski, M. Novel Drying Methods for Sustainable Upcycling of Brewers' Spent Grains as a Plant Protein Source. Sustainability, 12(9), 2020, 3660. doi:10.3390/su12093660.

7. Flood, M. Solar Prospects: The Potential for Renewable Energy. Wildwood House in association with Friends of the Earth, 1983.

8. Bal, L. M., Satya, S. and Naik, S. N. Solar Dryer with Thermal Energy Storage Systems for Drying Agricultural Food Products: A Review. Renewable and Sustainable Energy Reviews, 14(8), 2010, pp. 2298-2314. https://doi.org/10.1016/j.rser.2010.04.014.

9. Angula, J. P. and Inambao, F. L.Optimization of Solar Dryers Through Thermal Energy Storage: Two Concepts, International Journal of Mechanical Engineering and Technology, 13(10), 2020, pp. 2803-2813.

10. https://dx.doi.org/10.37624/IJERT/13.10.2020.2803-2813.

11. South Africa. Department of Energy. Renewable Energy - Solar Power.Pretoria: Government Printer, 2017. http://www.energy.gov.za/files/esources/renewables/r_solar.html.

12. Ekechukwu, O. V. Review of Solar Energy Drying Systems I: An Overview of Drying Principles and Theory. Energy Conversion and Management, 40(6), 1999, pp. 593-613.DOI: 10.1016/S0196-8904(98)00092-2.

13. Adekanye, T.A., Adegbenro, V.O., and Saliu, K.R. Development of Maize-on-Cob Dryer for Small Scale Farmers. Scientia Agriculture, 14(1), 2016, pp. 172-178. DOI: 10.15192/PSCP.SA.2016.14.1.172178.

14. Tiwari, A. A Review on Solar Drying of Agricultural Produce. Journal of Food Processing \& Technology, 7(9), 2016, pp. 623).doi: 10.4172/2157-7110.1000623.

15. Hellevang, K. J. Recommended Storage Moisture Contents and Estimated Allowable Storage Times. 2013. https://www.ag.ndsu.edw/publications/crops/grain-drying

16. Kaaya, A.N. and Kyamuhangire. Drying Maize Using Biomass-Heated Natural Convection Dryer Improves Grain Quality During Storage. Journal of Applied Sciences, 10(11), 2010, pp. 967-974. DOI: 10.3923/jas.2010.967.974. 
17. Saxena, A., Varun. and El-Sebaii, A.A. A Thermodynamic Review of Solar Air Heaters. Renewable and Sustainable Energy Reviews, 43, 2015, pp. 863-890. DOI: 10.1016/j.rser.2014.11.059.

18. Bujang, A. S. B. Properties and Bulk Drying of Biomass. Master's dissertation, Iowa State University, 2011. http://lib.dr.iastate.edu/etd/12104.

19. Cherubini, F., Bird, N. D., Cowie, A.Jungmeier, G., Schlamadinger, B. and Woess-Gallasch, S. Energy-and Greenhouse GasBased LCA of Biofuel and BioenergySystems: Key Issues, Ranges and Recommendations. Resources Conservation and Recycling, 53(8), 2009, pp. 434-447. DOI: 10.1016/j.resconrec.2009.03.013.

20. Johnson, J., Reicosky, D., Sharratt, B., Lindstrom, M. and Voorhees, W. Corn Stover as a Biofuel. USDA-ARS, North Central Soil Conservation Research Laboratory, Morris, MN. 2003

21. Bennett, A.S., Bern, C.J., Richard, T.L. and Anex, R.P. Corn Grain Drying Using Corn Stover Combustion and CHP systems. Transactions of the ASAE. American Society of Agricultural Engineers, 50(6), 2007, pp. 2161-2170. DOI: $10.13031 / 2013.24076$.

22. Lizotte, P.-L., Savoie, P. and De Champlain, A. Ash Content and Calorific Energy of Corn Stover Components in Eastern Canada. Energies. 8, 2015, pp. 4827-4838. doi:10.3390/en8064827.

23. Helsel, Z.R. and Wedin, W. F. Direct Combustion Energy from Crops and Crop Residues Produced in Iowa. Energy in Agriculture,1(80), 1983, pp. 317-329. DOI: 10.1016/0167-5826(81)90028-0.

24. AbhilashKidiyoor\&Kripa M Suvarna, "A Study on Performance of Solar Water Heater using 11 Lauric Acid-Water as Thermal Storage System”, TJPRC: International Journal of Heat and Mass Transfer (TJPRC: IJHMT) Vol. 1, Issue 1, pp, 914

25. NaveenRana, Mukesh Kumar, Ravi Kumar Goel\&Ankur Jain, "The Development and Prospect in the Solar Energy Sector in India”, International Journal of Mechanical and Production Engineering Research and Development (IJMPERD), Special Issue, $p p, 45-49$.

26. E. Shiva Prasad, M. AravindGoud\& R. Ravi Teja, “The Solar Powered Uninterrupted Power Supply System”, International Journal of Electrical and Electronics Engineering (IJEEE), Vol. 8, Issue 5, pp, 1-10.

27. V. M. Modi, H. N. Kadewal, J. R. Samariya\&AjinkyaDeshpande, “Comparative Study on Performance Evaluation of Solar Photovoltaic Module under Manual Tracking and Fixed Orientation Mode”, International Journal of Electrical and Electronics Engineering (IJEEE), Vol. 4, Issue 2, pp, 1-6 